\title{
Curriculum Model of Excellence Madrasah Ibtidaiyah in Indonesia
}

\author{
Yayan Carlian, Anas Salahudin \\ Jurusan Pendidikan Guru Madrasah Ibtidaiyah \\ UIN Sunan Gunung Djati \\ Bandung, Indonesia \\ yayan.carlian@uinsgd.ac.id, canassalahudin@uinsgd.ac.id
}

\author{
Ujang Dedih, Hariman Surya Siregar \\ Jurusan Pendidikan Agama \\ Islam UIN Sunan Gunung Djati \\ Bandung, Indonesia \\ ujangdedih@uinsgd.ac.id, \\ dharimansuryasiregar@uinsgd.ac.id
}

\begin{abstract}
The purpose of this research is to know the curriculum model from goal aspect, implementation procedure or content selection, and method aspect and evaluation of developed curriculum. The method used in this research is a qualitative approach using ethnographic method of case study. Technique of collecting data by interview, observation and document study. The location of this research is Madrasah Ibtidaiyah Negeri 2 Tangerang Selatan, Madrasah Ibtidaiyah Negeri I Palembang and Madrasah Ibtidaiyah Asih Putra. The results of the study as follows: curriculum model of the goal aspect must be comprehensiveness, consistency, attainability, suitability, validity and specificity. From the aspect of choosing, the contents of the curriculum should be significant; validity; social relevance; Utility, Learnability, Interest; In terms of curriculum, methods should consider the following criteria: Variety, Scope, Validity, Appropriateness and Relevance. In terms of curriculum evaluation, there are four dimensions that are considered in conducting curriculum evaluation, namely: evaluation of teachers in using curriculum, evaluation of curriculum design, graduate evaluation and evaluation of curriculum system.
\end{abstract}

\section{Keywords-curriculum model, exelent;}

\section{PRELIMINARY}

The curriculum has a strategic position in the development of education, which is a description of the vision, mission, and educational goals of a nation. This at once positions the curriculum as the central value-loads that will be transformed to learners. The direction and objectives of the educational curriculum will shift and change along with the dynamics of social change caused by various factors, both internal and external so that the curriculum adjustment [1] [2] is needed. Curriculum change is based on the results of analysis, evaluation, prediction and various challenges facing both internal and external changes. In this context, the curriculum as policy product is dynamic, contextual, and relative. Dynamic because it continues to grow and adjusted with the times and open to criticism. Contextual because it is very necessary and based on the context of its time, and relative because the resulting curriculum policy is considered good or perfect in its day, and will become irrelevant in the following epochs [3] [4] [5]. Therefore, the basic principle in curriculum policy is change and continuity that is continuous change [6], [7].
Curriculum development becomes one of the main tasks of the government to organize and develop education. Through the curriculum, the government outlines the purpose, function and objectives of national education on the content standards outlined in the direction of curriculum guidance [8]. Curriculum development is a comprehensive term, which includes several things including planning, implementation and evaluation. Curriculum planning is the first step in building a curriculum when the curriculum workers make decisions and take action to produce the planning that will be used by teachers and learners. Application of Curriculum or also called curriculum implementation trying to transfer curriculum planning into operational action.

Some of the reasons for the development of the Curriculum 2013 are: (1) changes in the learning process (from students told to year students) and the assessment process (from outputbased to process-based and output) requires additional hours of study; (2) the tendency of many countries to add hours of study; and (3) comparison with other countries shows lesson time in Indonesia with other countries is relatively short [9]. The direction of curriculum development in 2013 includes (1) strengthening characteristics, (2) using a scientific approach through observing, asking, trying, reasoning, communicating (3) using science as a driving force for all subjects, guiding students to find out, not to be told, (5) emphasizing language skills as communication tools, knowledge carriers and logical, systematic, and creative thinking, (6) measuring students' thinking level from low to high, (7) emphasizing the question (8) measuring the work processes of students, not just the work of students, and (9) using student learning portfolios [2].

Curriculum evaluation is the final stage of curriculum development to determine how much learning outcomes, the extent of achievement of planned programs, and the results of the curriculum itself [10] [11]. In curriculum development, it involves not only people directly related to the education world, but in it involves many people, such as politicians, entrepreneurs, parents of learners, and other elements of society who feel interested in education. The focus of this research is related to the curriculum model used and can be developed for Madarasah Ibtidaiyah (MI) Unggulan in Indonesia. The curriculum development model is an alternative procedure for designing, implementing, and evaluating a 
curriculum [5]. Therefore, the curriculum development model should be able to describe a process of learning planning system that can meet the various needs and standards of educational success [10] [12].

\section{RESEARCH METHODS}

This research uses descriptive analytical method with qualitative approach. This research takes place in three schools, namely: MIN 2 Tangerang, MIN 1 Palembang and MI Asih Putra Bandung. As for several reasonably significant reasons, why this research is carried out in all three schools because the school is included in MI excellence in Indonesia. Because this research uses multi case design study, the sampling technique of this research is used in two stages: (1) single case study in the first case used purposive sampling technique that is looking for key informant that can give information to the researcher about data needed. (2) The sampling method as in the first case is used to obtain data in the second and third cases. Data collection techniques used in this study include interviews, observation, and documentation studies.

\section{RESULTS AND DISCUSSION}

\section{A. Excellence of Curriculum MIN 2 Tangerang Selatan}

1) Featured Programs: MIN 2 Tangerang Selatan can be superior as it is today because developing a number of excellent programs, namely: (1) Developing the teaching of Al-Quran. (2) Teaching of prayer and other worship. (3) The cultivation of akhlakul karimah. (4) Out Door Activity. (5) Computer. (6) Memorize the Quran letters. (7) Fun English Club. (8) Extracurricular. Furthermore MIN 2 South Tangerang also developed a number of habits that strongly support the students' excellence, namely: Monday habituation ceremony and tausiyah; Tuesday learned to translate the Koran by using the Tamyiz method, Wednesday carrying out Inspiration Day, Thursday together memorized the selected letters, Friday carrying out the students santri. In addition, MIN 2 Tangerang Selatan has also developed a number of extracurricular programs: futsal, traditional dance, Islamic marawis, traditional arts (angklung), scouts / UKS, painting, martial arts (karate), theater, bands, recitations, and drumband.

2) Curiculum Structure: Basically the curriculum run in MIN 2 Tangerang Selatan develops according to the applicable regulations, ie the Curriculum 2013 is good for the material Religion general material as it is applicable in the current Sympathy. MIN 2 Tangerang Selatan is one of the schools established by the Directorate General of Education Decree No. 481 of 2015 as a mentoring mentor for the Curriculum 2013. The curriculum developed at MIN 2 is a national curriculum developed by the Ministry of Religious Affairs and by the Minister of Education and Culture. There is also a curriculum that is typically developed by MIN 2 Tangsel, namely: memorizing the 30th min for the class I-III and memorization of the letter of al-Baqarah for class IV-VI.
3) Graduation Guarantee: There is an interesting thing from MIN 2 Tangerang Selatan, namely that the madrasah dare to bolster the guarantee or guarantee to the graduates. There are a number of qualifications guaranteed to be owned by students of MIN 2 Tangerang Selatan graduates, namely: (1) Having a strong aqeedah. (2) Istiqomah in worship. (3) Tartil read al-quran. (4) Memorized Juz amma, some AlQuran and Hadith. (5) Devoted To the parents and respect to the teacher. (6) Unfortunately with friends and neighbors. (7) Discipline, (8) Caring, (9) Confidence, (10) Happy reading, (11) Have a life skill.

4) Achievment: Based on a well-defined vision, mission, and objectives, programs developed in a planned manner, and seriousness in implementing these programs, MIN 2 Tangerang Selatan has achieved a myriad of achievements in almost all fields. Among them: Gold Medal Category The Best Theory Mathematics field at the National KSM competition organized by Ministry of Religious Affairs RI. First Winner of KSM in Provinces organized by Banten Regional Office. Finalist of Mathematics Gasing SD 2013 National level performed by Surya Instutute. Finalist of Mathematics Olympiad Fakhrudin Ar-Razi Competition National level organized by IPB. 3rd Winner of Quiet Precious Quran in Jabodetabek held Lajnah Pentashih Quran Ministry of Religious Affairs of Indonesia. Hope III MHQ Jabodetabek held Lajnah Pentashih Quran Ministry of Religious Affairs of Indonesia. 3rd Winner of Al-Qur'an Translation Puitization in Jabodetabek at 14th Islamic Book Fair 2015. 2nd Winner Drawing on Jabodetabek Blacu Bag 15th Islamic Book Fair 1437H / 2016 Gelora Bung Karno Senayan. Champion 1 Dai Cilik Jabodetabek 15th Islamic Book Fair 1437H / 2016 Gelora Bung Karno Senayan. Champion 1 Hafizh Quran Juz 30 Jabodetabek 15th Islamic Book Fair 1437H / 2016 Gelora Bung Karno Senayan. In addition, the students of madrasah, head of madrasah, and teachers MIN 2 South Tangerang also many achievements. Among them are Mother Jetty Maynur had been a national model teacher in 2008, Mrs. Feti Fathiyah has also been a model teacher of Banten province in 2014, Laelatus Sa'adah became Aflatoun Kreatif teacher in 2013, became the winner of Healthy Madrasah Competition at Banten Province level in 2014, and received the Madrasah Award from Kemenag Banten Province 2015.

\section{B. Excellence of Curriculum MIN 1 Palembang}

In accordance with the vision and mission of the madrasah, then MI Negeri 1 Palembang developed a program of excellence established based on the existing internal capabilities. This program of excellence is aimed at building characteristic of MI Negeri 1 Palembang, but also to increase the community's trust and the popularity of madrasah. The advantages programs are as follows:

1) Religious Activity / Improvement of Faith and Taqwa (Imtaq): This program is a flagship for MI Negeri 1 Palembang, an activity that is packed in religious nuances, 
dilaksaakan continuously and permanently scheduled and systematic. This program is in the form of activities of habituation and religious skills, namely: the activities of dzuhur prayers in congregation, Ashar prayers in congregation, and memorized juz 'amma performed every day. The activity in particular is IMTAQ Saturday, which is scheduled from 07.00 up to 0830 WIB. With the material activities include: Dhuha Prayer in congregation, Yaasiin sura reading and Asma'ul Husnah, and the formation of ahklaqul karimah in the form of taushiah.

2) English Club dan Arabic Club: This study club program was formed to address global challenges through language. This program aims to build practical skills for students in language communication with kominitas study club including: story talling, vocabulary, speech and discussion. This activity is held on Friday at 10:30 to 11:30 pm.

\section{Excellence of MI Asih Putra Bandung Curriculum}

The curriculum content of Madrasah Ibtidaiyah Asih Putera covers a number of subjects whose breadth and depth is a burden of learning for learners in educational units. In addition, local content material and self-development activities are included in the curriculum content. Local content is a curriculum activity to develop potentials tailored to the characteristics and potential of the coma, including regional excellence, whose material is not appropriate to be part of the subject matter of the other and / or too much so that it should be a subject of its own. The substance of local content is determined by the unit of education, not limited to the subject of skill training. The local content is the subject, so the education unit should develop standards of competence and basic competence for each type of local content held. The education unit can hold one local content subject each semester. This means that in each year an educational unit can organize two local content subjects. Self-development is an activity that aims to provide opportunities for learners to develop and express themselves in accordance with the needs, talents, interests, each learner in accordance with the condition of madrasah. Each self-development is facilitated and / or guided by counselors, teachers, or educational personnel that can be done in the form of extracurricular activities. Selfdevelopment activities can be carried out, among others, through counseling services related to personal and social issues, learning, and career development of learners as well as scouting activities, leadership, and youth scientific groups. Self-development for special education units emphasizes the improvement of life skills and independence according to the special needs of learners. self-development is not a subject.

Some research on the superior Madrasah so that we can easily know the characteristics. In his dissertation on the leadership of Elementary School / MI achievement, Imron Arifin did not mention MIN Malang I as the Excellence MI but MI achievement with the criteria of academic achievement (as measured by student achievement in ebtanas) and nonacademic achievement (as measured by school achievement in winning various (2) good academic and special services, (3) good planning, (4) working climate and (5) applying classroom teachers and teachers in the field of study, (7) provision of basic education in the form of preschool education, (8) high expectations and strong support from parents and the surrounding community, (9) involvement of vice principals and teachers, and (10) effective principal leadership.

1) The purpose of the curriculum: Here's a simple explanation of Aims, Goals, and Objectives: The term aims is used as an educational goal that is the hope and desire of a society, or what the curriculum expects or wants to achieve broadly. Or in other words, aims is the goal of an education in general and shows a relatively long period of time and is valid for several years. Meanwhile, the term goals are used for more specific purposes than aims. Obviously goals are the curriculum goals outlined in aims. Usually cultivated in nontechnical language, also directed at achieving student achievement by improving content and skills. Another way to conceptualize goals is to consider them as a way of an institution and organization along with the community in helping to achieve educational goals. Therefore, if for example the purpose of the education system is to enable students to read and count, then the goal is the way an educational institution generally achieves that goal. Goals are goals that are long-term goals. Selanjunya Objectives is the most specific curriculum objective formulation, ie what students should learn through interaction with a curriculum. Objectives emphasize changes in student behavior. Objectives are the elaboration of aims and goals, and expressly stated, using technical language and behavioral terms required knowledge management in developing curricula that are appropriate to the purpose and development of the times [13][14].

Effective Objectives are: 1) Comprehensiveness. The purpose of this curriculum should be formulated by considering the inputs of which are from various professions and must consider the developments of the times and economic developments that occur. Comprehensive means the objectives of the formulated curriculum must include the three cognitive, affective, and psychomotor domains. 2) Consistency. The purpose of the curriculum should be to look at the relationship effectively and consistently with other elements. One source of clutter or ambiguity of purpose is when this particular purpose is formulated without reference to the general objective (aims, goals). 3) Attainability. The objectives of the formulated curriculum should be made possible by the students. 4) Suitability) "conformity with the needs of the student and who is eligible to determine the suitability". The curriculum developers agreed that the objectives of the curriculum should be structured according to the needs of the students. 5) Validity. Objectives must reflect the reality of what they mean, or the goal must describe what they want to accomplish. 6) Specificity [12], [11], [7]. The purpose of the education must be formulated precisely, clearly and specifically. Objectives that are not clear and not specific will be difficult to understand both by students and by teachers. Especially by teachers, it will be difficult to implement and realize it. Therefore, this goal should be structured in the form of clear and specific behavioral formulations. 
2) Contents of the curriculum: The contents of the Curriculum are teaching materials in teaching and learning process that includes knowledge, skills and values associated with the delivered teaching materials. To be an effective teacher, the authors mention the contents of the curriculum as follows: 1) Knowledge that contains facts, principles, and generalizations that exist in teaching materials. 2) Educational knowledge includes methods used by teachers in teaching so that students really understand the teaching materials. 3) Knowledge Curriculum, ie understanding of curriculum context to teach knowledge about teaching materials.

Criteria for the selection of curriculum content the author proposes 6 criteria for choosing the contents of the curriculum, namely 1) Significant; with knowledge and discipline, the balance between concepts, ideas and facts. 2) Validity; content must be authentic, correct and accurate. 3) Social relevance; related to moral values, ideal, social issues, controversy issues. 4) Utility (useful); preparing students to live more "adults". 5) Learnability (can be learned); can be used by students with different backgrounds and abilities. 6) Interest; based on the interest (interest) of students. While the scope of curriculum content refers to the breadth and depth of the curriculum at one time. In determining the scope of the content of the curriculum, the authors suggest some concepts of Time Constraint, A Common core, Special needs of Content, Integration of Content and A total amount of content required (number of contents required).

The preparation of the material must also consider the sequence. Claims are the composition of the curriculum content presented to learners. There are six criteria for sorting the contents of the curriculum as suggested by Robert Zais: from simple to complex, prerequisite learnings, chronology, from whole to parts -to-part learning), from concrete to abstract (increasing abstraction) and Spiral sequencing (Spiral Sequencing).

3) Curriculum Methods: Selection of methods may require more treatment than other curriculum components. The impact of the method is very important, and in this section we will describe the importance of choosing the method as the main part of the curriculum component. The method is how a teacher activates the contents of the curriculum, because the content of the curriculum will mean to the student if the teacher can mentranmisikannya in various ways. There is no single best method, just as all curriculum components are essentially equally important. To improve student's learning efficiency, the teacher must be able to choose the most suitable method from so many methods. Some of the criteria in choosing a method and regardless of the formulation of the objectives are: 1) Principles of learning. 2) Identify the learning activities undertaken. In addition to the two criteria mentioned above, there are other criteria: 1) Variety: methods must vary to achieve goals and can accommodate different levels and learning styles of students. 2) Scope is a method should be quite varied in achieving all the objectives that have been formulated. 3) Validity is a special method must be related to the parts of the objective formula. 4)
Appropriateness of the method should be related to students' interests, abilities and readability. 5) Relevance is the method used must relate to what is needed after the student graduated study. Research is concerned with the method of showing and suggesting that students' involvement in curriculum planning should be further enhanced, therefore consideration of student involvement in the selection of future methods should be increasingly considered in the effort to select the curriculum content and achievement of objectives.

4) Curriculum Evaluation: There are four dimensions of curriculum evaluation that is 1) Evaluation of teachers in using the curriculum. The teacher's evaluation of the use of the curriculum logically is the first thing to do. This is done by observing the data of teacher use to the curriculum. When the teacher does not use the curriculum in the development of the learning strategy, the evaluation is stopped. 2) Evaluate curriculum design. Design evaluation is the most difficult evaluation because of the absence of criteria in its implementation. Different designs certainly can not be compared and adapted to the general criteria. Although we do not learn much about how to compare curriculum design A with B curriculum design with an adequate supervision, we can evaluate the induvidual that is part of the curriculum design. One such example is "goal and objectives. When a number of general and specific goals are expressed in a curriculum, the priority objectives may be evaluated first. Delphi techniques or some other techniques can help this task. If a curriculum includes a specific purpose of behavior, then clarity is important to evaluate. 3) Graduate Evaluation. The next evaluation is curriculum assessment as an instrument to predict graduates. 4) Evaluation of curriculum system. Every aspect of the curriculum should be under the supervision of the evaluation. Poor system because it is less vital. Feedback from the evaluation system should be available to facilitate system repair. The selection of the arena, the selection of the people involved, the organization of the people to work, the work procedures, the tasks played by personal leadership are all subjects that must be evaluated in both their advantages and disadvantages [11]. This is what makes the curriculum system work. Feedback from the evaluation can help to improve the system and provide sustainability and development of the curriculum system from year to year. The criteria of the implementation of a good curriculum evaluation are as follows: 1) Continuity is the evaluation must be done continuously and is an integrated part in every part of learning and teaching. 2) Scope: evaluation procedures should vary as coverage of objectives. 3) Compatibility: the evaluation should be compatible with the goal formulation. 4) Validity: evaluation procedures should measure what should be measured. Test must also be reliable, eg consistent in the measurement. 5) Objectivity: evaluation must be based on objectivity, and avoid that leads to subjectivity and 6) Diagnostic value: evaluation should recognize the level of student performance and the process required to achieve that performance. 7) Participation ie evaluation procedure is 
possible to be improved by the students themselves. While the evaluation model is used, curriculum developers can select various evaluation models that are conceptually conceptualized by curriculum evaluation experts.

5) Development of Superior MI: Simply put, the chart below shows an integrated curriculum model for madrasah where the field of study of Islamic clan consisting of Aqeedah Akhlak, Fiqh, Quran Hadith, History of Islamic Culture and the creation of a religious environment atmosphere should be a commitment for every madrasah in order to realize the madrasa as a vehicle for fostering the spirit and practice of Islam. The field of Islamic religious studies is the core so that the materials contained in the field of general studies PKN, IPS, Science, Mathematics, Cultural Art, Penjaskes, Local Content, Skills and Languages must be imbued by Islamic religious education. The field of Islamic studies is also a motivator and dynamicator for the development of the quality of IQ (Intelligent Quotient), EQ, (Emotional Quotient), CQ (Creativity Quotient) and SQ (Spritual Quotient).

The development of characteristic of religious madrasah can also be marked by the existence of various activities such as the increase of religious education programs optimally such as the addition of religious lessons, the avoidance of educational activities dichotomized between religious education with general education, the realization of religious atmosphere which is reflected in the life of worship and behavior, widespread extra-curricular activities that focus on the development of the whole personality and the increasingly maintained implementation of Islamic teachings in schools such as kekeluragaan, self-esteem, spirit of togetherness and others. The purpose of developing the superiority of madrasah by the author here is: First, the mastery of two foreign languages (Arabic and English). One of the hallmarks of the madrasah is that there is a field of Arabic study that must be studied by learners other than English or other foreign languages. This fact should be well utilized by Madrasahs to create a flagship program by focusing on how to facilitate students to master a foreign language for those with the ability or for students who have talents and interests in this direction.In order for the effectiveness of the implementation, the madrasah must have readiness in various matters, especially on; 1) Readiness of dormitory for students who follow this program. Dormitory readiness is important in order to create a language environment (al-lugah) 2) Readiness Dormitory for the ustazd and utadzah who will guide them during the program. 3) Professional readiness of teachers in language learning. 4 readiness of funds both for teacher salaries and for other costs such as fees for learning process, 5) Readiness of facilities and learning parasaran like a language laboratorium. There are at least three standards of competence that are expected to have students who follow this excellent program is; 1) Can use foreign language actively with oral. This means that they should be able to use foreign languages (English and Arabic) actively with others correctly, as well as to correctly understand the language expressed by native speakers. 2) Can understand the language of the book or language of the book. This means students understand the language of the book written in Arabic using the science of sharaf, balagah, nahwu) as the ingredients, as well as the
English language. 3) Can make writing using Arabic according to rule of faith. This means, they can express their ideas and thoughts in writing that use foreign language. Second, the Development of Choice Packages Program. Third, Entrepreneurship of the four professional Da'i Programs.

\section{CONCLUSION}

Curriculum MIN 2 Tangerang Selatan is divided into several programs, namely teacher program, teaching program, KKG program, library program, laboratory program, qiro'ati program and tahfidzul qur'an, homeroom program, student program, and there are some excellent programs, is to develop the teachings of the Quran, the teachings of prayer and other worship, the cultivation of akhlakul karimah, outdor activity, computers, memorization of Al-Quran letters, fun English club and extracurricular. The curriculum of MIN 1 Palembang is divided into several programs in line with the curriculum objectives of MIN 1 Palembang, while the objectives are improvement of faith and piety, improvement of academic quality, improvement in nonacademic / extracurricular field, improvement in hygiene and reforestation and improvement in business school health. While the excellence of the curriculum MIN 1 Palembang is very thick religious activities / improving faith and taqwa and the existence of English club and Arabic club. Curriculum MI Asih Putra Bandung carry out two types of curriculum, namely Education Unit Level Curriculum (KTSP) and Curriculum 2013. The advantages of MIN Asih Putra Bandung is a local content that is, Sundanese, English and Self Development Activities. In addition, there are life skills education and education programs based on local excellence. The model of MI curriculum in terms of objectives should be comprehensiveness, consistency, attainability, suitability, validity and specificity. In terms of the selection of curriculum content should be significant, validity of social relevance, utility, learnability and interest. In terms of curriculum, methods should consider the following criteria: Variety: Scope, Validity, Appropriateness and Relevance.

\section{REFERENCES}

[1] H. Widyastono, Pengembangan Kurikulum di Era Otonomi Daerah., Jakarta: PT. Bumi Aksara, 2014.

[2] Ruwiyah, "Implementasi dan Pengembangan Kurikulum 2013 pada Madrasah Aliyah," Jurnal IAIN Gorontalo, 2015.

[3] N. Syaodih, Pengembangan Kurikulum (Teori dan Praktek), Bandung: Remaja Rosdakarya, 2010.

[4] Sukirman, Pengantar Kurikulum, Bandung, 2010, p. 6.

[5] T. P. MKDP, Kurikulum dan Pembelajaran, Jakarta: Rajawali Pers, 2011.

[6] I. Machali, "Kebijakan Perubahan Kurikulum 2013 Menyongsong Indonesia Emas 2045,” Jurnal Pendidikan Islam : Volume IIII, Nomor 1, Juni 2014/1435., vol. 3, no. 1, 2014.

[7] N. C. o. Educational, Basic in Education, Newdelhi: Publication Divsion by the Secretary, National Council of Educational Research and Training, Sri Aurobindo Marg, 2014.

[8] S. B. Raharjo, "Quality Evaluation of Education Trend in Indonesia," Jurnal Penelitian dan Evaluasi Pendidikan, vol. 16, no. 2, p. 511, 2012.

[9] T. Penyusun, Bahan Uji Publik Kurikulum 2013, Jakarta: Kemdikbud, 2012. 
[10] N. Sudjana, Pembinaan dan Pengembangan Kurikulum di Sekolah, Bandung: Sinar Baru, 2005.

[11] M. Q. Patton, How To Use Qualitative Methods in Evaluation., Yogyakarta: Pustaka Pelajar, 2006.

[12] J. D. Neil, Curriculum A Comprehensive Introduction., a Division of Scott Foresman and Company, 1980.

[13] M. Tisna, "Tisna, M. Pengembangan Model Kurikulum Pendidikan Agama Islam (PAI) Menuju Masyarakat Ekonomi Asean (MEA).," AtTurats Jurnal Pemikiran Pendidikan Islam, 2016.

[14] J. Seema A. Tarnekar, "Framework for a Knowledge Management System for Curriculum Development Process," Journal of Information \& Knowledge Management, vol. 3, no. 4, 2014 